\title{
TIME SERIES HYDROLOGIC MONITORING WITHIN KARST AQUIFERS OF KEY CAVE AND CATHEDRAL CAVERNS, ALABAMA
}

\author{
Gheorghe M. L. Ponta
}

Geological Survey of Alabama, 420 Hackberry Lane, Tuscaloosa, Alabama, 35405, USA, gponta@gsa.state.al.us

\section{Stuart W. McGregor}

Geological Survey of Alabama, 420 Hackberry Lane, Tuscaloosa, Alabama, 35405, USA, smcgregor@gsa.state.al.us

\section{Randall Blackwood}

Cathedral Caverns State Park, 637 Cave Road,Woodville, Alabama 35776, randall.blackwood@dcnr.alabama.gov

\begin{abstract}
Cave ecosystems in north Alabama provide vital habitat for the federally endangered Alabama Cavefish (Speoplatyrhinus poulsoni), Alabama Cave Shrimp (Palaemonias alabamae), and Gray Bat (Myotis grisescens). Furthermore, Key Cave has been designated as critical habitat for the Alabama Cavefish, which is known only from pools within the cave. Cathedral Caverns also has a diverse aquatic fauna, but none of its members are currently afforded protection. Time series data were collected using data loggers on an hourly/daily schedule from November 2017 to July 2019 to determine aquifer water quality characteristics (water level, specific conductance, temperature patterns, and water quality baseline) in the areas within and around Key Cave National Wildlife Refuge and Cathedral Caverns State Park. One cave and two wells were monitored in and near Key Cave National Wildlife Refuge and one cave and one well were monitored in and near Cathedral Caverns State Park. A rain gauge was installed at each site to evaluate waterlevel response to precipitation events. Reservoir pool level of Pickwick Lake of the Tennessee River, adjacent and hydraulically connected to Key Cave, was provided by the Tennessee Valley Authority (TVA). Streamflow at Cathedral Caverns was measured in the cave and at a spring outflow. Sites were visited monthly to download data and perform routine maintenance, and once a year to collect water samples. Samples were analyzed for major anions and cations, nutrients, and total organic carbon.
\end{abstract}

There are some differences between sites in baseline water chemistry, specific conductance, and temperature values in response to precipitation. The major ionic composition of water collected from Key Cave and Cathedral Caverns is dominated by calcium and bicarbonate ions. Temperature varied at Key Cave from $11.7^{\circ} \mathrm{C}$ to $18.3^{\circ} \mathrm{C}$ and between $10.2^{\circ} \mathrm{C}$ and $24.3^{\circ} \mathrm{C}$ at Cathedral Caverns. Conductance ranged between 226 and $428 \mu \mathrm{S} /$ $\mathrm{cm}$ at Key Cave and 52 to $383 \mu \mathrm{S} / \mathrm{cm}$ at Cathedral Caverns. Water levels at Key Cave Wildlife Refuge changed $6 \mathrm{~m}$ in the cave, $3 \mathrm{~m}$ in Pickwick Reservoir (TVA), $5 \mathrm{~m}$ in Blue Hole Well (077Y26001), and $6.4 \mathrm{~m}$ at Key Cave Well (077Y10001). At Cathedral Caverns State Park, water levels fluctuated $10.8 \mathrm{~m}$ in the cave and $1.9 \mathrm{~m}$ at Anderson Well.

The purpose of these studies was to delineate the recharge area and aquifer characteristics of each cave to enable local, state, and federal agencies and interested citizens to develop, manage, and protect the water resources that support these species.

Key words: karst, caves, springs, sinkholes, cross sections

\section{Introduction}

Key Cave is located in the Tennessee River drainage ba$\sin$ in south-central Lauderdale County, Alabama about $8 \mathrm{~km}$ southwest of Florence in an area underlain by the Mississippian-age Tuscumbia Limestone and Fort Payne Chert (Figure 1). Key Cave and the immediate vicinity comprise the Key Cave National Wildlife Refuge, a satellite of Wheeler National Wildlife Refuge, and is designated for protection of an assortment of federally protected and state conservation priority species, with no public access and stringently restricted access to professional researchers (Ponta et al., 2018).

Cathedral Caverns is also in the Tennessee River drainage basin, located approximately $8.0 \mathrm{~km}$ northeast of Grant in Marshall County, Alabama, an area underlain by stratigraphically upper Mississippian-age Bangor and Monteagle limestones (GSA, 2018). Cathedral Caverns 


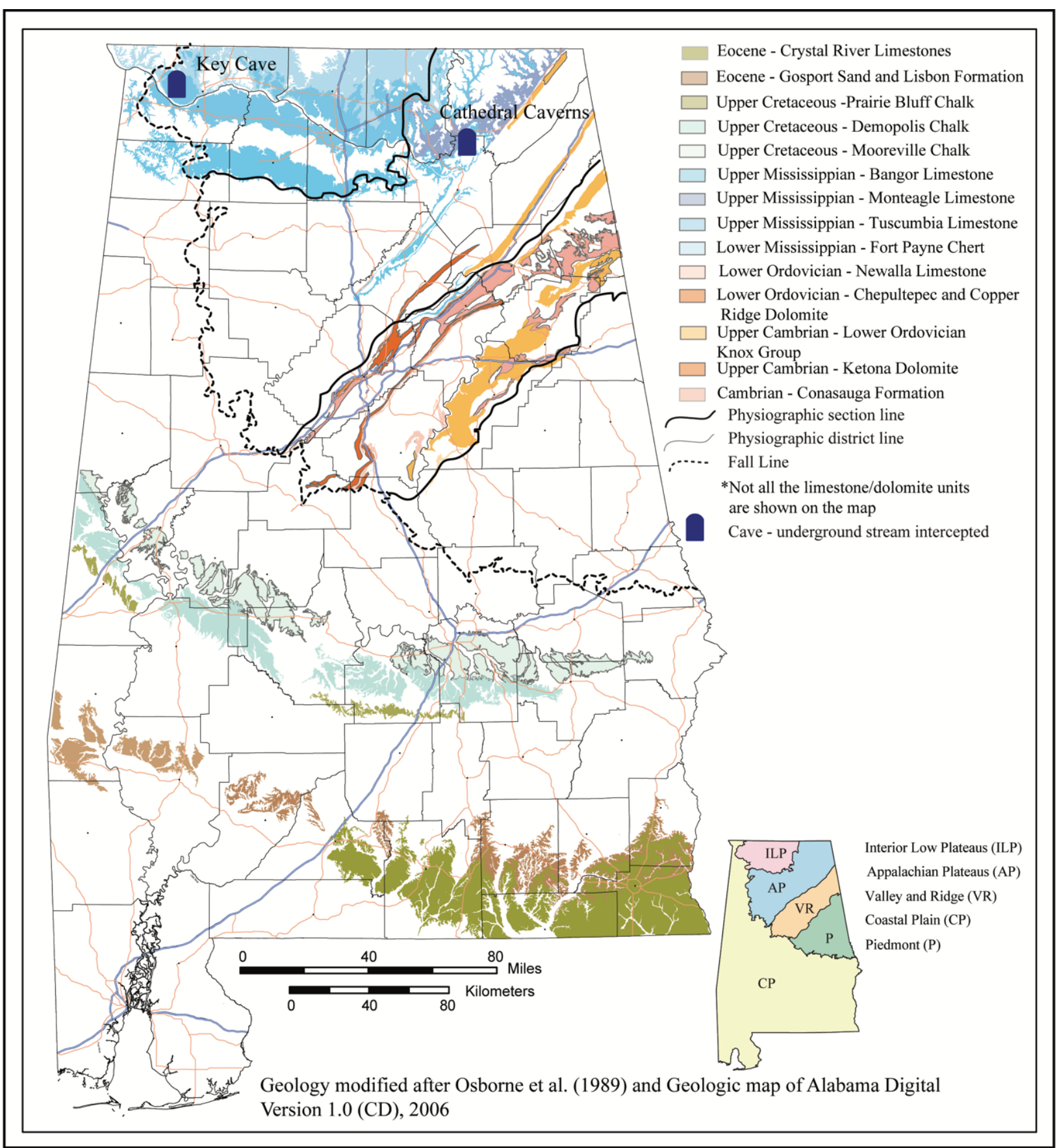

Figure 1. Karst and potential karst areas in soluble rock in Alabama with locations of Key Cave and Cathedral Caverns. Not all limestones/dolomites units are shown on the map (modified from Ponta, 2018).

and the immediate vicinity comprise a state park open to the public. Karst features in both areas include sinkholes, springs, caves, and sinking streams. Sinkholes are more frequent in Interior Low Plateaus Province where Key Cave is located, and caves are abundant in Appalachian Plateaus Province where Cathedral Cavern is situated (Ponta, 2018).

\section{Methods}

Time series data were collected using one OTT ecoLog 800 data logger installed in Key Cave where water level, specific conductance, and temperature are measured every hour and data are transmitted to the Geological Survey of Alabama (GSA) office daily using cellular communications technology. Two nearby wells are 
equipped with OTT Orpheus Mini pressure transducers and data loggers.

Various instruments and methods are used in the analyses of water samples by the GSA Geochemical Laboratory. Equipment used for water sample analyses included a Leeman Labs Prodigy inductively coupled atomic-emission plasma spectrometer, a Perkin-Elmer Model AAnalyst600 Zeeman graphite furnace atomic absorption spectrometer, a Thermo Scientific Dionex Aquion ion chromatograph, a Seal AA3 Segmented Flow Analyzer, a Shimadzu UV1800 ultraviolet-visible spectrophotometer, a Leeman Hydra cold-vapor atomic fluorescence spectrophotometer, a Shimadzu TOC-L, and a YSI Model 5000 meter. Water analyses were conducted in accordance with established GSA procedures based on methods delineated in USEPA (1983, 1991), Fishman and Friedman (1989), and Greenburg and others (1992). Quality assurance/quality control procedures for the collection, preservation, and retention times of water samples were in accordance with O'Neil and Meintzer (1995).

\section{Key Cave}

Key Cave is located approximately $91 \mathrm{~m}$ north of the Tennessee River and is developed in the Tuscumbia Limestone with pools of water interconnected with the Tuscumbia Limestone aquifer. Water levels, specific conductance, and temperature were measured continuously from December 2017 through August 2019, when an OTT probe/ transducer was installed. Seasonal fluctuations up to $6 \mathrm{~m}$ were observed in this pool, which demonstrates the unconfined nature of this aquifer in the vicinity of the cave.

Of primary importance to the protection of Key Cave and its aquifer is the presence of the Alabama Cavefish. The Alabama Cavefish was described by Cooper and Kuehne (1974) from a series of nine specimens collected from March 1967 to May 1970. Another keystone species in Key Cave is the federally endangered Gray Myotis. Key Cave is considered a priority one maternity cave for the species and, based on past emergence counts, on average about 20,000 to 30,000 Gray Myotis over-summer in Key Cave annually (Rob Hurt, USFWS, written comm., October 3, 2018). It is currently recognized by the State of Alabama as a species of Highest Conservation Concern (Shelton-Nix, 2017).

Key Cave contains 3,338 m/10,953 feet of mapped passages (Alabama Cave Survey/ACS, 2019) with an exten- sion $^{1}$ of $360 \mathrm{~m} / 1,180$ feet and branching index ${ }^{2}$ of 9.28 (Povară et al., 1990). Based on these coefficients, Key Cave is a labyrinthic type cave (Figure 2) or fissure, network maze (Palmer, 2007). From a hydrogeologic point of view, it is a base-level spring cave or a water table cave with preponderant autogenic recharge.

Geographic information systems (GIS) mapping for this project was conducted using ArcMAP software (Ebersole and Hill, 2016). In addition, the 2011 LiDAR data for Lauderdale County was used to create a bare-ground Digital Elevation Model (DEM) using the Create LAS dataset tool and the LAS dataset toolbar in ArcMAP (Ebersole, unpublished map, 2017).

The Key Cave recharge area covers over $51 \mathrm{~km}^{2} / 20 \mathrm{mi}^{2}$, based on dye studies performed in 1986 and the early 1990s, (Aley, 1986, 1990) and Kidd et al. in 2001. A modified version of the International Association of Hydrogeologist (IAH) legend was used on Figure 3 (Ponta, 2019). The legend shows only the aquifers types present on each map (Figures 3 and 9).

A hydrogeologic cross section was produced to show the relationships between different geologic formations in the Key Cave Wildlife Refuge. Two wells were located in the study area in the Tuscumbia Limestone and Fort Payne Chert (Figure 4).

Well 077-Y-10-001 (Blue Hole Well) with a total depth of $25.5 \mathrm{~m}$ is an unused domestic supply well in the northcentral part of the study area (7.2 km north of Key Cave) The well is constructed in the Tuscumbia Limestone and Fort Payne Chert aquifer. The initial water level was recorded at $148 \mathrm{~m}$ above mean sea level (MSL) in May 2018 and continuous water level measurements were made through August 2019, with a few short data gaps (Figure 5). Water levels declined from the initial measurement in May 2018 through a minor drought in JuneSeptember 2018, then stabilized through November and declined again in the summer of 2019. Significant seasonal fluctuations of around $5 \mathrm{~m}$ are depicted on the hydrograph, indicative of an unconfined aquifer.

Well 077-26-Y-001(Key Cave Well) is a domestic supply well located $2 \mathrm{~km}$ northwest of Key Cave and constructed

'Distance between the furthest points of a cave on the map.

${ }^{2}$ Branching index is the ratio between the length of the cave and extension. 


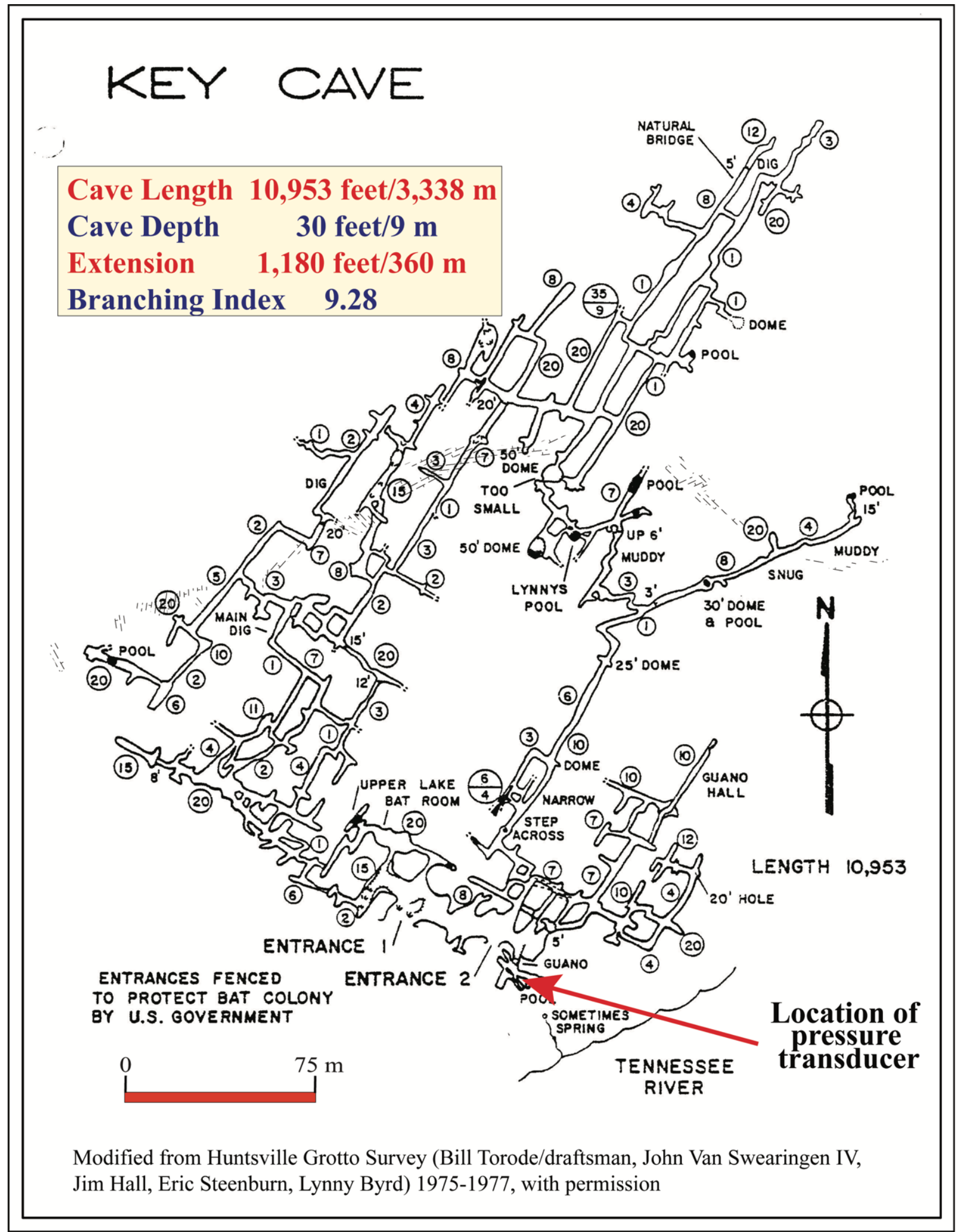

Figure 2. Key Cave map. 


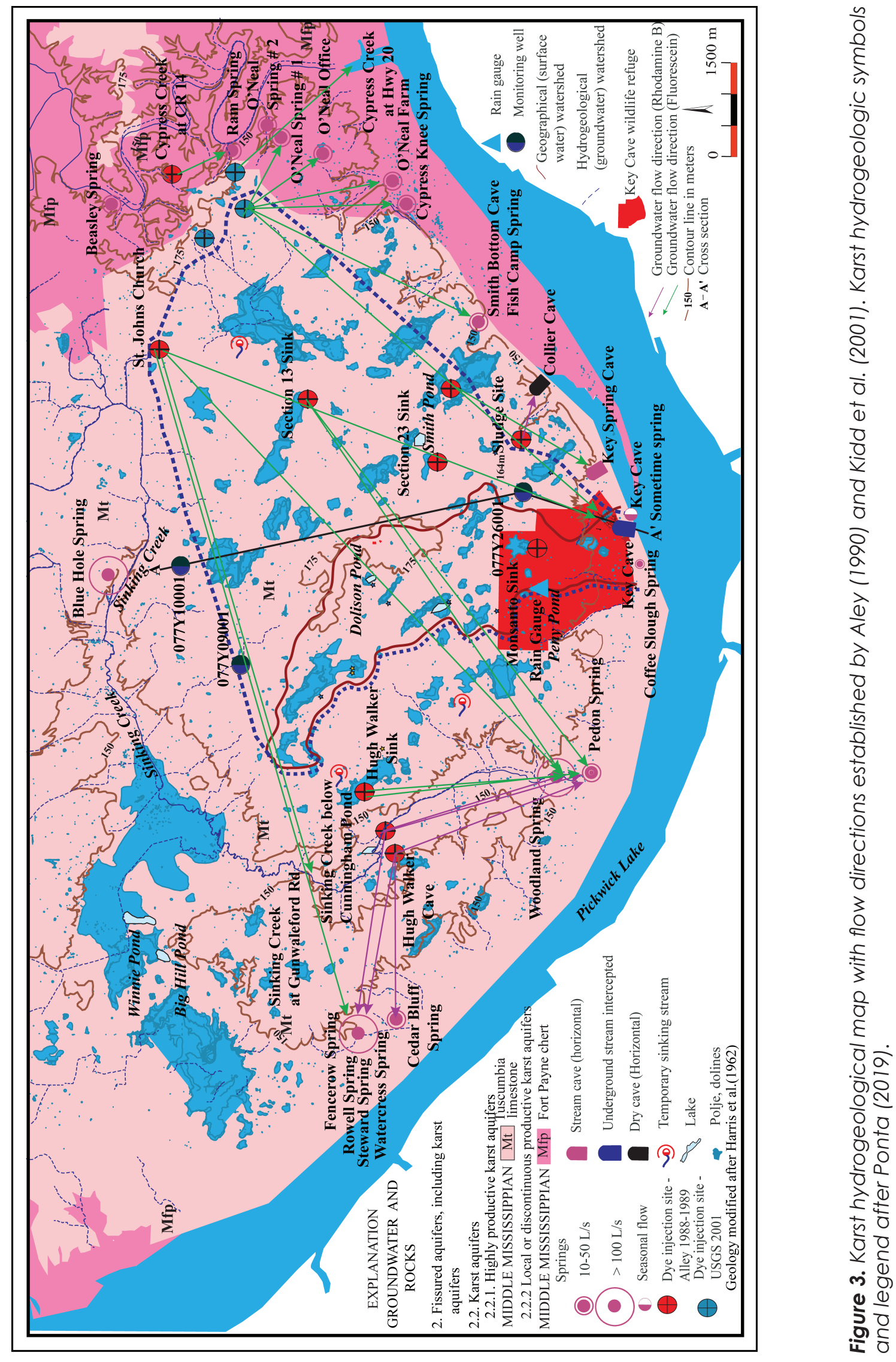




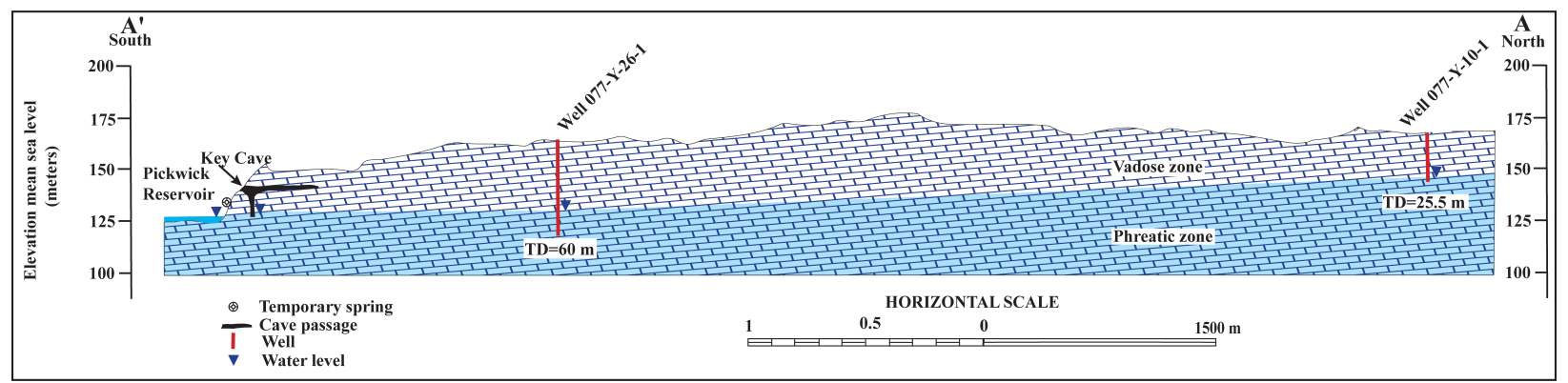

Figure 4. Hydrogeological cross section between wells 77 Y 10 001, 77 Y 26 001, Key Cave, and Pickwick Reservoir.

in the Tuscumbia Limestone and Fort Payne Chert aquifer. The initial water level was measured at $129 \mathrm{~m}$ MSL in May 2018 followed by continuous measurements through July 2019, with minor data gaps (Figure 5). Seasonal fluctuations of water level up to $6.4 \mathrm{~m}$, depicted on the hydrograph, are indicative of an unconfined aquifer.

The shallowest water levels in the Tuscumbia Limestone and Fort Payne Chert aquifer occurred in an area near the northern updip limit of the aquifer (well 077-Y-10-001) south of the Blue Hole (spring), and deeper water levels were encountered near the Tennessee River.
500 to $600 \mathrm{~L} / \mathrm{s}$. The recharge area of this spring has not been determined and it is very possible the recharge area extends to the Florence city limits. As such, the spring could be vulnerable to contamination. Blue Hole spring is located in the headwaters of Sinking Creek, the main surface feature in the area aside from the Tennessee River, and flows mostly over limestone and chert. It is very possible that Sinking Creek loses some water from this spring to recharge the Key Cave aquifer. Due to the location of this spring and the possibility of a connection to the Key Cave aquifer, GSA recommends sampling this spring in the future.

The largest spring in the area, located $8 \mathrm{~km}$ north of Key Cave, is Blue Hole Spring, with an estimated flow of

Results of water-level investigations in and around Key Cave indicate that the hydrology of the cave is likely

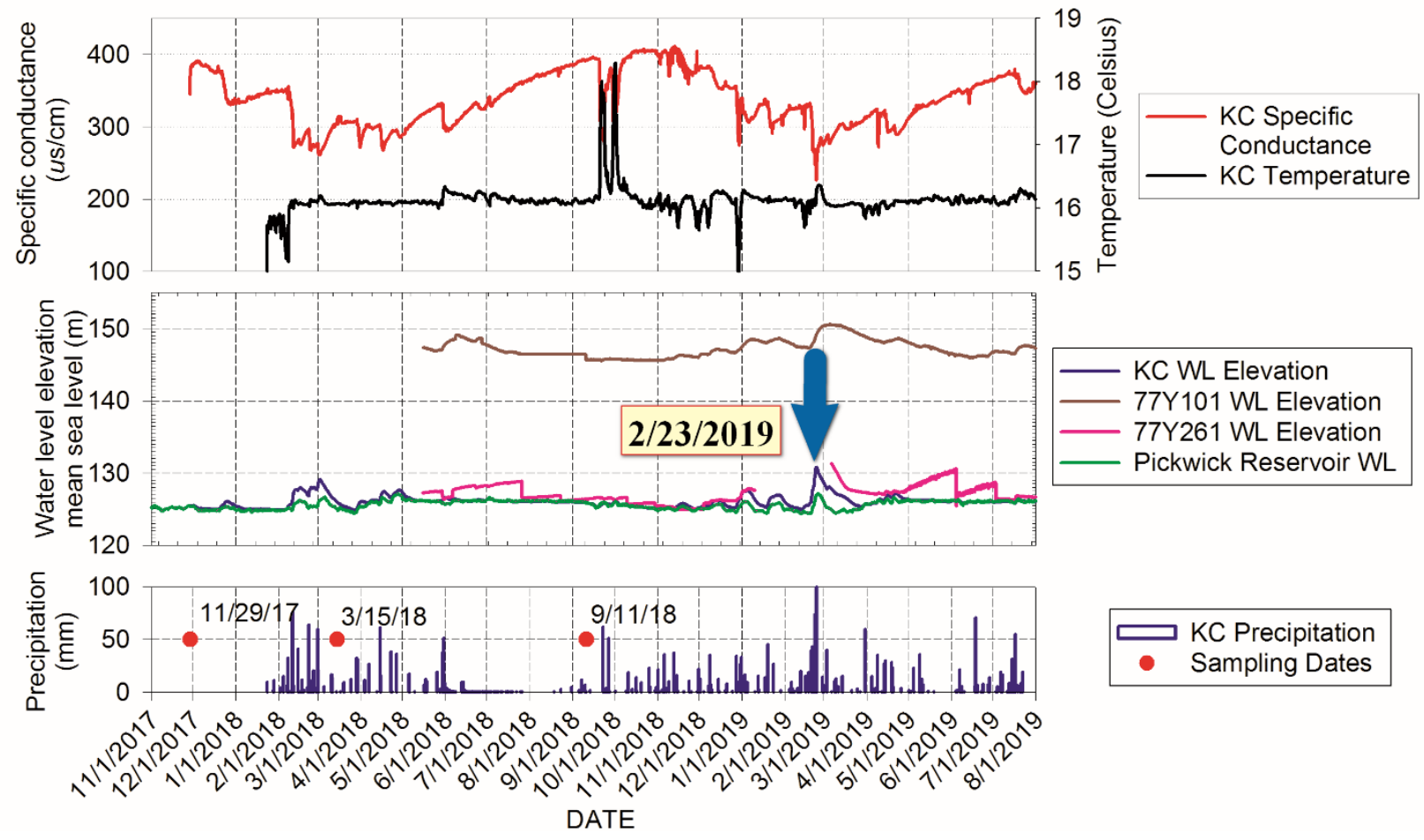

Figure 5. Plot of specific conductance and water level in Key Cave, water wells $077 Y 10001$ and 077Y2600 1, and Pickwick Reservoir with precipitation from November 1, 2017 to August 1, 2019. 
controlled by groundwater originating in the soils and shallow karst terrain around the cave (epikarst/vadose zone) and direct conduits through which surface runoff enters the cave during storm events, and a phreatic zone component recharged several kilometers away from the cave (Figures 3 and 4). As shown on the cross section, the water level elevation between monitoring wells and Key Cave define a gentle slope towards the Tennessee River, at the interface between vadose and phreatic zones.

These findings suggest that Key Cave is a phreatic/ aquifer/lentic/water table cave most of the time, with a stream component (vadose cave) after abundant precipitation as in January/February 2019 (110.32 mm) when Key Cave Sometime Spring was flowing. The last documented flow was recorded in 1990 by Aley.

Plots of daily parameter measurements for specific conductance, temperature, and surface water elevation are depicted in Figure 5, along with daily precipitation records provided by the rainfall station located about $1.7 \mathrm{~km}$ to the northwest of Key Cave (Figure 3). The rainfall events can be directly correlated with rising water level in Key Cave. Average water level in Key Cave is highest from January through April and lowest from August through October. The maximum water surface elevation measured since 2017 was recorded on February 23, 2019, at $130.8 \mathrm{~m}$ MSL (Figure 6). The area had received $110.34 \mathrm{~mm}$ of rain that day. Water usually exits only through Coffee Slough Spring (Aley, 1990), an underwater spring about $125 \mathrm{~m}$ west of Key Cave. During storm events, additional water enters the system generating a stream in the cave which resurfaces at Key Cave Sometime Spring, which was observed flowing in March 2019. The greatest variation of water level was recorded in February and early March, when the area received a large amount of rain, and subsequently greater quantities of surface water runoff. Water is present continuously in isolated pools in Key Cave.

Key Cave has a very stable water temperature regime throughout the year and ranged from 11.7 to $18.3^{\circ} \mathrm{C}$ and averaged around $16.0^{\circ} \mathrm{C}$ for the monitored period (Figure 5). Temperature generally was constant between February and September, with large variations after storm events. During a winter/spring storm event the temperature decreased with rising water level. After a summer storm event the temperature rose along with water level

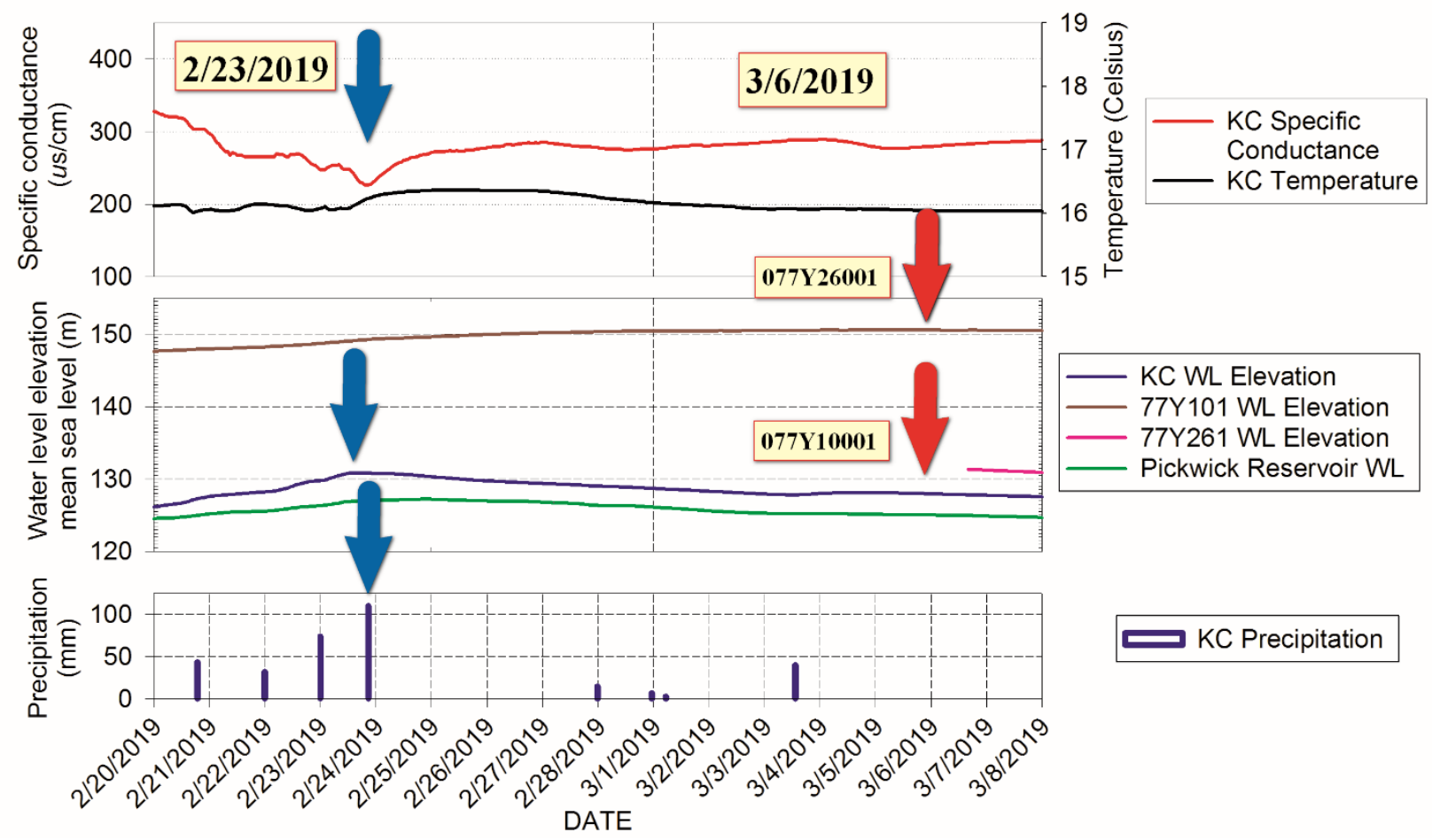

Figure 6. Plot of specific conductance and water level in Key Cave, water wells 077Y10001, 077Y26001, and Pickwick Reservoir with precipitation from February 20 to March 8, 2019. The water level response in the wells is 11 days later. 
elevation. In both scenarios, a rapid return to ambient water temperature and conductance was recorded. Figure 5 also shows the water level elevation of Pickwick Reservoir, demonstrating its interconnection with the water in Key Cave. The graph overlapped the water level elevation at all times except during large storm events, when the water-level elevation of Pickwick Reservoir is lower due to control by the dam operator.

Figure 5 also depicts the water-level elevations of two domestic wells, one located about $2 \mathrm{~km}$ northeast of Key Cave and the second about $7.2 \mathrm{~km}$ north of the cave. Both graphs depict a descending trend of the water level which is in agreement with water-level elevations of Key Cave and Pickwick Reservoir for the period monitored.

Figure 6 shows the immediate effects of a substantial rain event on February 23, 2019, with an immediate rise in water level and decrease in specific conductance in the cave pool. The two wells monitored nearby at the site, recorded a slight water level rise only on March 6, 2019 (two weeks later) confirming the complexity of the karst aquifer.

\section{Water Quality}

Water samples were collected from three sites in the Key Cave area in December 2016 and three more times from Key Cave in November 2017 and in March and September 2018. Sampling was performed in accordance with the Alabama Department of Environmental Management's (ADEM) guidelines found in Alabama's Water Quality Assessment and Listing Methodology (ADEM, 2010). Water-quality parameters measured in the field with an YSI Professional Plus instrument included specific conductance, $\mathrm{pH}$, dissolved oxygen, oxidation/reduction potential (ORP), and temperature.

The quality of groundwater in Key Cave is controlled by surface runoff into the cave, solubility conditions between the surrounding limestone and groundwater, and quality of groundwater from phreatic aquifers that contribute to the cave's water supply. Average specific conductance for the monitoring period ranged from $226 \mu \mathrm{S} /$ $\mathrm{cm}$ to $428 \mu \mathrm{S} / \mathrm{cm}$. During winter months, higher water levels typically result in lower specific conductance and temperature values. During summer months (after heavy rains), higher water levels typically result in lower specific conductance and higher temperature values.
At Key Cave, the minimum $\mathrm{pH}$ measured was 7.3 and maximum was 7.6. The highest DO was $12.2 \mathrm{mg} / \mathrm{L}$ recorded in November 2017 (range 7.1 to $12.2 \mathrm{mg} / \mathrm{L}$ ).

The major ionic composition of water collected from Key Cave Wildlife Refuge, as illustrated by the Piper diagrams in Figure 7, is dominated by calcium and bicarbonate ions.

Water collected from Key Cave exhibits an average alkalinity of $192.75 \mathrm{mg} / \mathrm{L}$, hardness $-215.63 \mathrm{mg} / \mathrm{L}$, TDS $-229.5 \mathrm{mg} / \mathrm{L}, \mathrm{Ca}^{2+}-83.06 \mathrm{mg} / \mathrm{L}$, and $\mathrm{SO}_{4}^{2-}-2.66 \mathrm{mg} / \mathrm{L}$ values.

Chloride ranged from 4.21 to $5.10 \mathrm{mg} / \mathrm{L}$ in Key Cave samples. The elevated chloride concentration in Key Cave indicates a possible connection to polluted runoff affecting the groundwater. Sulfate concentration ranged from 1.67 to $3.72 \mathrm{mg} / \mathrm{L}$.

Analytical results indicated the presence of $\mathrm{NH}_{3}$ concentrations in November $2017(0.02 \mathrm{mg} / \mathrm{L})$ and September 2018 (0.04 mg/L) in Key Cave. Ammonia concentrations exceeded the background concentration level of $0.01 \mathrm{mg} / \mathrm{L}$ for uncontaminated streams (Maidment, 1993) at this site. However, the toxicity limit $(0.5 \mathrm{mg} / \mathrm{L})$ was not exceeded in any of the samples collected during the project period.

The critical nitrate concentration of surface water for excessive algae growth is $0.5 \mathrm{mg} / \mathrm{L}$ (Maidment, 1993). The limit was exceeded in all four water samples collected during this project, ranging from 2.75 to $3.52 \mathrm{mg} / \mathrm{L}$. Generally, an inverse correlation between nitrate concentrations and water level elevation was observed. All samples collected in Key Cave had an elevated concentration of nitrate due, in part, to the presence of the guano in the vicinity of the cave pool.

Total phosphorus (total-P) concentrations in water samples collected in the Key Cave area exceeded the $0.05 \mathrm{mg} / \mathrm{L}$ total-P limit for excessive algal growth in three of the four samples. Key Cave samples ranged between 0.04 and $0.09 \mathrm{mg} / \mathrm{L}$. High concentrations measured at Key Cave were associated with high-water level. However, it is possible that the total-P concentrations measured in Key Cave are related to the presence of guano in the cave pool.

Lead $(\mathrm{Pb})$ is pervasive throughout aquatic systems, but none of Key Cave water samples exceeded the USEPA pri- 


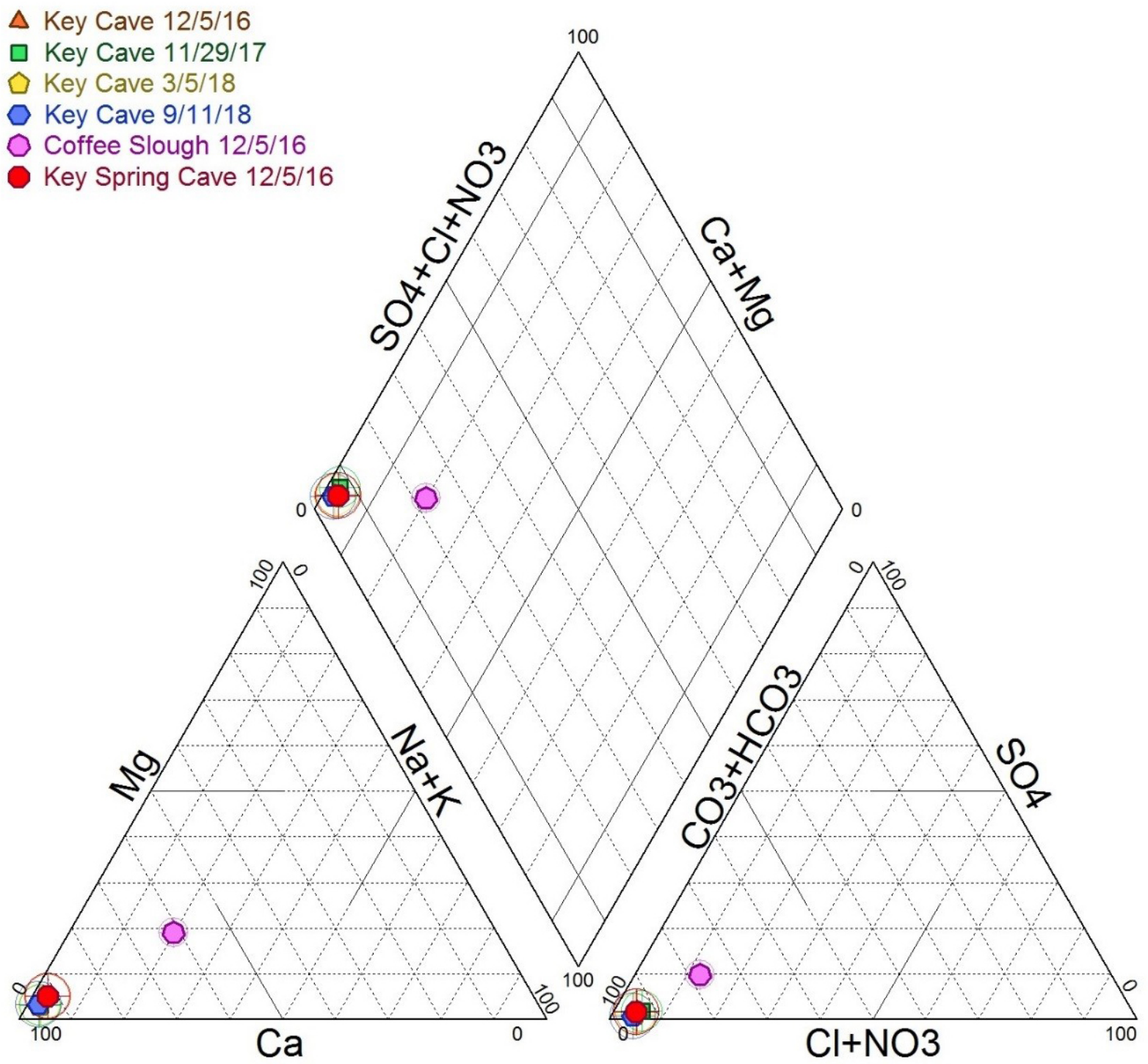

Figure 7. Piper trilinear diagram showing major ion composition of water collected from the Key Cave Wildlife Refuge area.

mary/secondary drinking water standard for lead of $15 \mu \mathrm{g} / \mathrm{L}$ (USEPA, 1996). The highest concentration was measured in November $2017(2.27 \mu \mathrm{g} / \mathrm{L})$ which corresponded to the lowest $\mathrm{pH}$ value recorded during the sampling event.

Iron (Fe) concentrations did not exceed the USEPA (1996) primary/secondary drinking water standard of $300 \mu \mathrm{g} / \mathrm{L}$ at any sites. The highest concentration of iron $(9.1 \mu \mathrm{g} / \mathrm{L})$ was recorded at Key Cave in March 2018. Iron was below detection limit at all other sampling events.

Aluminum (Al) was not detected at any of the sites and did not exceed the USEPA (1996) primary/secondary drinking water standards of $60 \mu \mathrm{g} / \mathrm{L}$ in any of the sam- ples. Barium $(\mathrm{Ba})$ concentration ranged between 14.8 to $22.7 \mu \mathrm{g} / \mathrm{L}$ in all samples. Manganese (Mn) concentrations did not exceed the USEPA (1996) primary/secondary drinking water standard of $50 \mu \mathrm{g} / \mathrm{L}$ at any sites.

A limited group of organic constituents were analyzed in collected water samples. They include total organic carbon (TOC), phenol, and oil and grease. At Key Cave TOC was detected only in December 2016 at a concentration of $1.23 \mathrm{mg} / \mathrm{L}$.

\section{Cathedral Caverns}

Cathedral Caverns has 3,356 m/11,012 feet of mapped passages (ACS, 2019) with an extension of $621 \mathrm{~m} / 2,040$ 


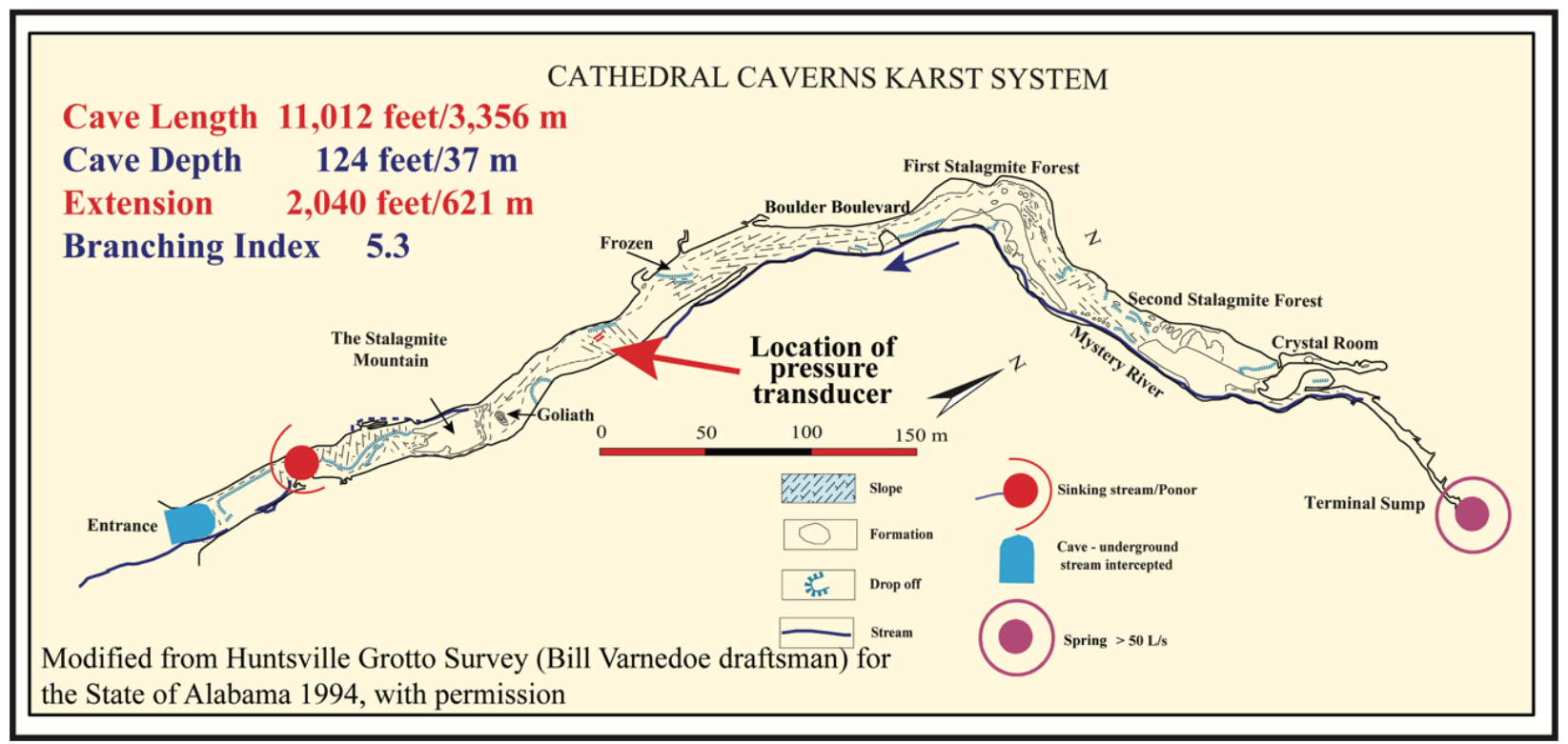

Figure 8. Cathedral Caverns map.

feet and branching index of 5.3. Based on these coefficients, Cathedral Caverns is a branchwork type cave with a stream at the water table (Figure 8) with preponderant allogenic recharge. The Cathedral Caverns watershed covers over $20 \mathrm{~km}^{2} / 8 \mathrm{mi}^{2}$.

A pressure transducer was installed on a bridge in the central part of the cave. The large fluctuations of water level during precipitation events is controlled by a small restriction located downstream of the bridge along the Mystery River, which cannot take large amounts of water after a significant rain event, creating a temporary lake.

As shown on the karst hydrogeological map of the area (Figure 9), the main sinking point feeding the underground stream is Dry Branch, with waters derived from impervious rocks and springs.

Based on these findings we can say that Cathedral Caverns is a vadose cave or a cave with a stream at the water table. Anderson Well, located $750 \mathrm{~m}$ southwest of the cave (Figure 10), is installed in the phreatic zone and has no connection with the cave stream. Cathedral Caverns Well is used by the park for cave maintenance (not drinking water) and is completed in such a way that it cannot be monitored.

In addition, the karst hydrogeological map of the site shows the Mystery River (Figure 8) disappearing underground in the vicinity of the cave entrance and, based on monthly discharge measurements in the cave and at the spring, our assumption is that these waters discharge through Cathedral Caverns Spring, located $1 \mathrm{~km}$ south. Between the Cathedral Caverns entrance and the spring, there should be another cave which is waiting to be found/discovered.

Plots of daily parameter measurements for specific conductance, temperature, and surface water elevation are depicted in Figure 11, along with daily precipitation records provided by the rainfall station located at Cathedral Caverns (Figure 9). The rainfall events can be directly correlated with rising water level in the cave. Average water level in Cathedral Caverns is highest from January through April and lowest from August through October. The maximum water surface elevation measured since 2017 was recorded on February 24, 2019, at 221.75 m MSL. The area had received $297 \mathrm{~mm}$ of rain between February 12 and 24,2019 . The greatest variation of water level was recorded in February and the beginning of March, when the area received a large amount of rain, and subsequently greater quantities of surface water runoff.

Cathedral Caverns' water temperature regime throughout the year ranged from $10.2^{\circ} \mathrm{C}$ to $24.3^{\circ} \mathrm{C}$ with large variations after storm events. Figure 12 depicts the water level elevations between November 5 and 20, 2018 showing an $88 \mathrm{~mm}$ rain event on November 8, 2019 with a water level rise in the cave 5 days later associated with an increase of specific conductance in the cave stream (opposite Key Cave). The rain's effect in the cave stream 


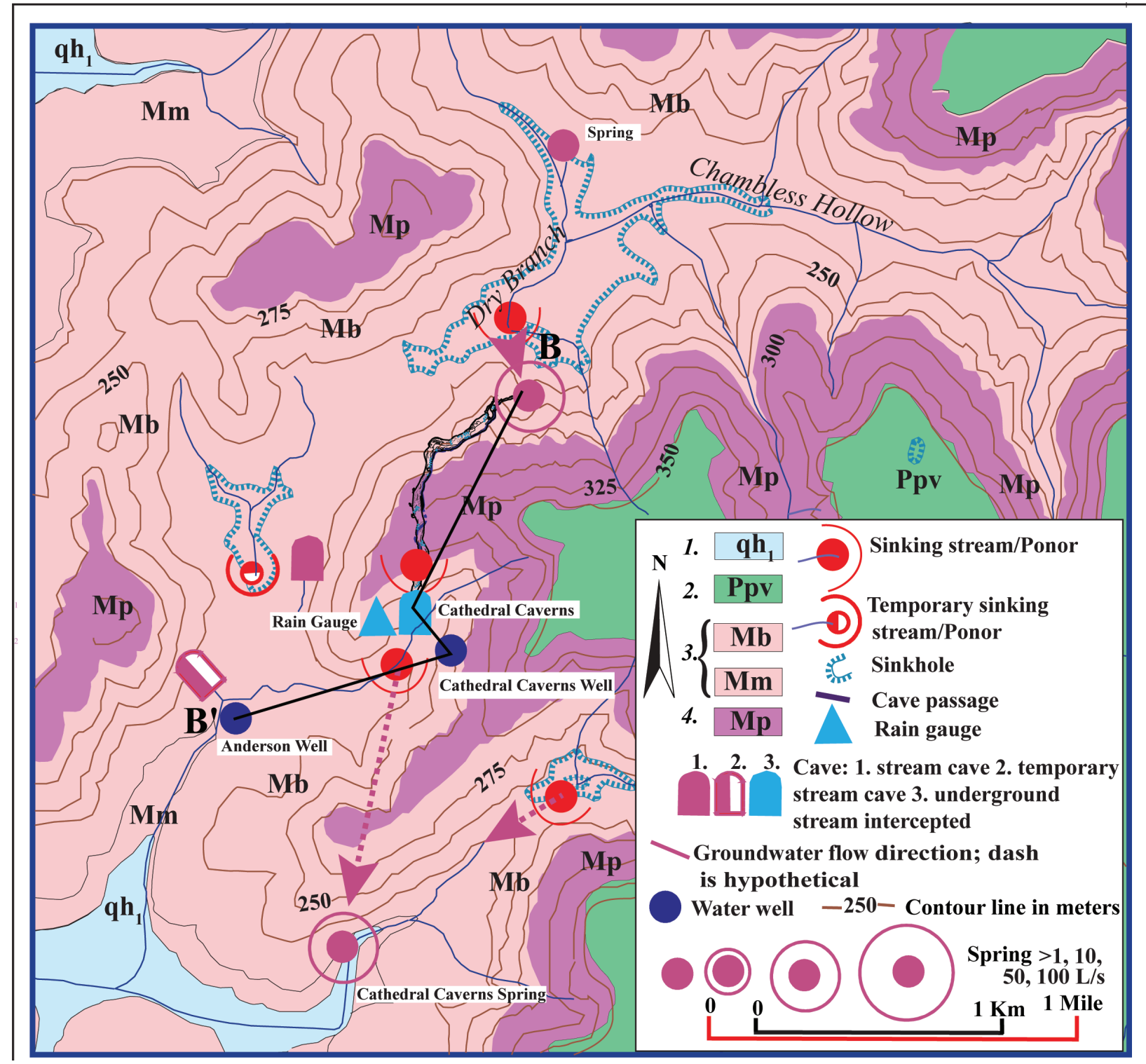

Figure 9. Hydrogeological map of the Cathedral Caverns area. 1. Local or discontinuous productive aquifers, or extensive but only moderately productive aquifers: qh 1- Quaternary. 2. Extensive and highly productive aquifers: Ppv - Pottsville formation. 3. Highly productive karst aquifers: Mb - Bangor limestone Mm-Monteagle limestone. 4. Local or discontinues productive karst aquifers: Mp Pennington Formation. Karst hydrogeological symbols and legend after Ponta (2019)

was not recorded until February 13, 2019 (5 days later), confirming the complexity of the karst aquifer.

\section{Water Quality}

Only one water sample was collected from Cathedral Caverns, on February 2, 2017 next to the transducer.

Average specific conductance for the monitoring period ranged from $52 \mu \mathrm{S} / \mathrm{cm}$ to $383 \mu \mathrm{S} / \mathrm{cm}$. During winter months, higher water levels typically result in higher specific conductance and temperature values. Seasonal fluctuations up to $10.81 \mathrm{~m}$ were observed in the river. At Cathedral Caverns, the minimum $\mathrm{pH}$ measured was 6.58 and maximum was 8.11 with a medium of 7.68 . The highest DO was 9.96 recorded as December 2, 2017 (range 6.67 to $9.96 \mathrm{mg} / \mathrm{L}$ ).

Water sample collected from Cathedral Caverns exhibits hardness $-69 \mathrm{mg} / \mathrm{L}$, TDS $-118 \mathrm{mg} / \mathrm{L}, \mathrm{Ca}^{2+}-22.6 \mathrm{mg} / \mathrm{L}$, and $\mathrm{SO}_{4}{ }^{2-}-7.49 \mathrm{mg} / \mathrm{L}$ values. Chloride was $3.91 \mathrm{mg} / \mathrm{L}$. 


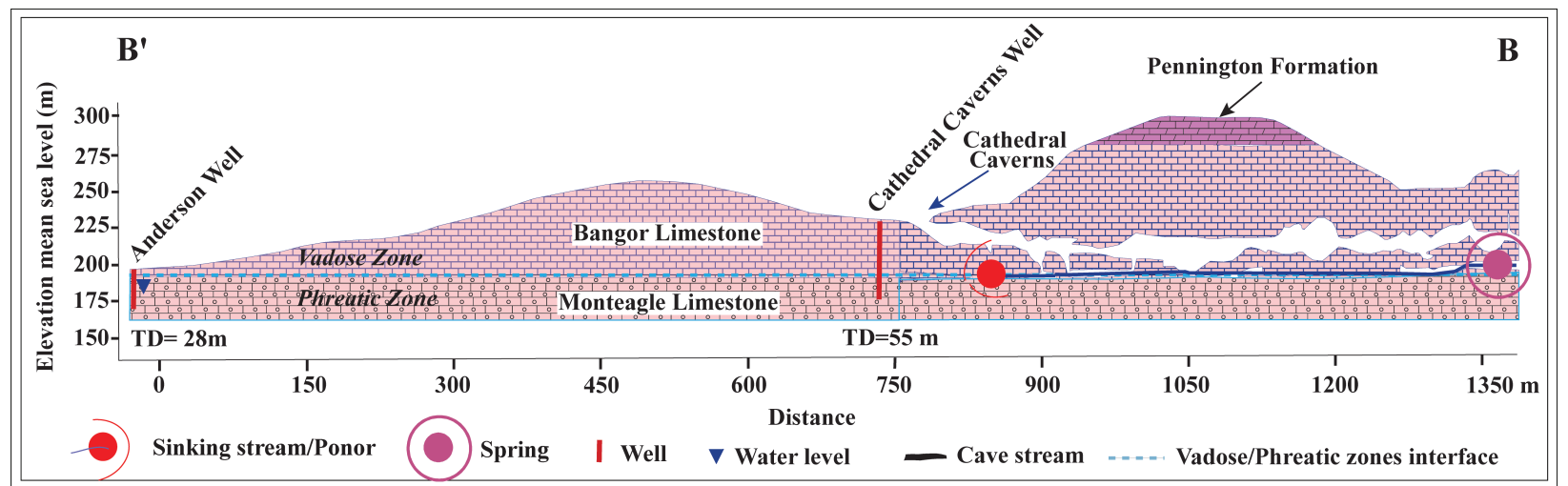

Figure 10. Hydrogeologic cross section of Cathedral Caverns.
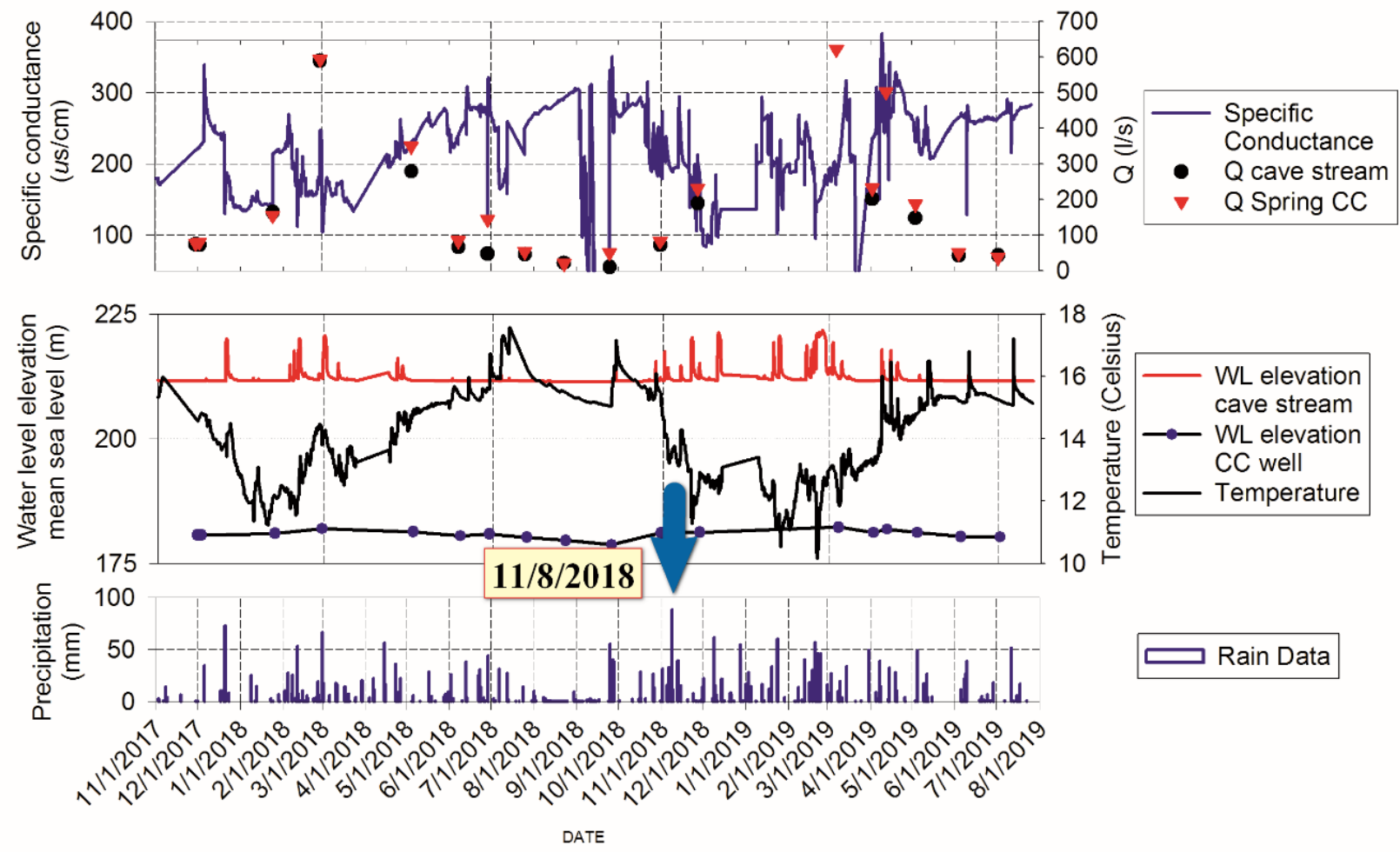

Figure 11. Plot of specific conductance and water level in Cathedral Caverns and water well 095A29002r with precipitation and discharge measurements from November 1, 2017 to August 1, 2019.

The elevated chloride concentration in Cathedral Caverns indicates a possible connection to polluted runoff affecting the groundwater.

The critical nitrate concentration of surface water for excessive algae growth is $0.5 \mathrm{mg} / \mathrm{L}$ (Maidment, 1993). That nitrate limit was exceeded in the water sample collected in the cave, with a value of $3.01 \mathrm{mg} / \mathrm{L}$. Barium (Ba) concentration was $0.023 \mathrm{mg} / \mathrm{L}$.

A limited group of organic constituents were analyzed in the collected water samples. They include total organic carbon (TOC) and phenol. Only TOC was detected at a concentration of $2.61 \mathrm{mg} / \mathrm{L}$.

\section{Conclusions}

Parameters investigated in this study exhibit seasonal, as well as spatial, variability. In the investigated aquatic systems, specific conductance values varied with water level elevation, discharge, and contaminant concentration. Given the association of higher SC values with low water level elevation/ flow events, it is possible that waters with higher contaminant levels during low water level elevation/ 


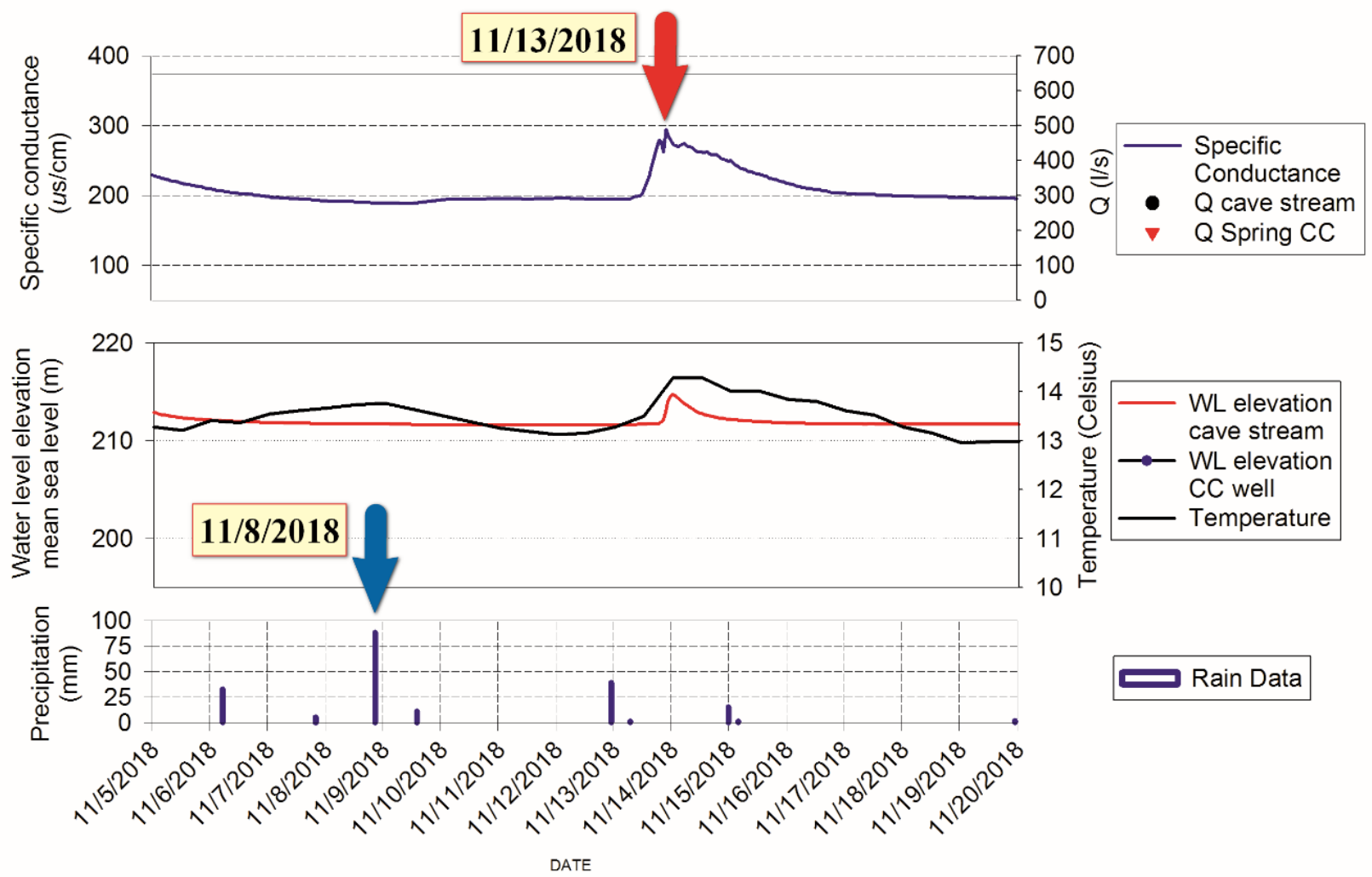

Figure 12. Plot of specific conductance and water level in Cathedral Caverns and water well 095A29002 with precipitation and discharge measurements from November 5 through 202018.

flow events are diluted during higher water level elevation/discharge episodes.

The low levels of ammonia suggest that nitrate in the pool/stream waters may originate from the nitrification of ammonia in the unsaturated zone. Furthermore, high nitrate concentrations are associated with elevated chloride concentrations. Consequently, the presence of nitrate may be associated with leaching of residual nitrate from soil when the photosynthesis process is dormant. Metals, with the exception of lead, which is pervasive in the investigated waters, do not pose a contamination problem in the Key Cave area. No lead concentrations were above the USEPA primary/secondary drinking water standard of $15 \mu \mathrm{g} / \mathrm{L}$ (USEPA, 1996). Aluminum (Al), barium $(\mathrm{Ba})$, iron $(\mathrm{Fe})$, and manganese $(\mathrm{MN})$ concentrations did not exceeded the USEPA primary/secondary drinking water standards.

Overall, the analytical data indicate that the investigated waters are affected by agricultural practices and developed land from surrounding areas. The presence of highly conductive soils in the study area and relatively low topographic relief results in an environment favorable to rapid water infiltration and reduced runoff rates. Therefore, contaminants, such as nitrate, will migrate through the soil to the saturated zone.

Additionally, analytical data suggest that shallow groundwater may have a greater input of nutrients to deep groundwater than runoff.

Most of the field parameters measured at the site and the values of constituents from Cathedral Caverns are significantly lower. More than likely this difference is a result of two types of caves: a water table/aquifer/phreatic cave (Key Cave) and a Vadose Cave (Cathedral Caverns). In a phreatic cave the water flow is substantially slower, permitting sufficient time for limestone to be dissolved and conductance values to rise.

\section{Acknowledgments}

The authors would like to acknowledge the Geological Survey of Alabama Groundwater Assessment Program team that made this work possible. In addition, we would like to acknowledge the Alabama Cave Survey, which 
provided access to their caves database. Acknowledgment is made to the residents and landowners of the study area who graciously allowed access to their property and furnished information on wells and springs and other significant data. Rob Hurt and Lee Holt of the USFWS also provided valuable assistance to the study.

\section{References}

Alabama Cave Survey 2018, Key Cave, http://www. alabamacavesurvey.org. Accessed May 18, 2019.

Alabama Department of Environmental Management, 2010, Alabama's Water Quality Assessment and Listing Methodology.

Aley T. 1986. Hydrogeologic investigations for a proposed landfill near Florence, Alabama: Report prepared for Waste Contractors, Inc., 20 p.

1990, Delineation and hydrogeologic study of the Key Cave aquifer, Lauderdale County, Alabama: Report prepared for U.S. Fish and Wildlife Service, contract number 14-16-004-99-073, 114 p.

Cooper JC, Kuehne RA. 1974. Speoplatyrhinus poulsoni, a new genus and species of subterranean fish from Alabama: Copeia, 1974, no. 2, p. 486-493.

Ebersole S, Hill M. 2016. Karst supplemental data to the National hydrography dataset for northern Alabama watersheds, Geological Survey of Alabama Open-File Report 1609, 13 pages and GIS data.

Fishman MJ, Friedman LC, eds. 1989. Methods for determination of inorganic substances in water and fluvial sediments: U.S. Geological Survey, Techniques of Water-Resources Investigations, Book 5, Chapter A1, 545 p.

Geologic map of Alabama Digital Version 1.0 (CD), 2006.

Geological Survey of Alabama. 2018, Assessment of groundwater resources in Alabama, 2010-16: Alabama Geological Survey Bulletin 186, 426 p.

Greenberg AE, Clesceri LS, Eaton AD, eds. 1992. Standard methods for the examination of water and wastewater: Washington, D.C., American Public Health Association.
Harris HB, Peace RR, Jr., Harris WF, Jr. 1962. Geological map of Lauderdale County: Alabama Geological Survey Map 18, 1 plate.

Kidd RE, Taylor CT, Stricklin VE. 2001. Use of ground-water tracers to evaluate the hydraulic connection between Key Cave and the proposed industrial site near Florence, Alabama, 2000 and 2001, U.S. Geological Survey Water-Resources Investigation Report 01-4228, 21 p.

Maidment DR, ed. 1993. Handbook of hydrology: New York, McGraw-Hill Inc., p. 11.37-11.54.

O’Neil PE, Meintzer RE. 1995. Lower Cahaba River water quality assessment/quality assurance/quality plans for the collection and analysis of water quality and aquatic biological samples: Alabama Geological Survey unpublished report, 50 p.

Osborne WE, Szabo MW, Copeland CW, Jr., Neathery TL. 1989. Geologic map of Alabama: Alabama Geological Survey Special Map 221, scale $1: 500,000$.

Palmer AN. 2007 Cave Geology; Cave Books USA p. 454

Ponta GM. 2018. Geologic framework of karst aquifer systems in Alabama in Sasowsky ID, Byle MJ, and Land L (eds), Proceedings of the 15th Multidisciplinary Conference on Sinkholes and the Engineering and Environmental Impacts of Karst and the 3rd Appalachian Karst Symposium: Carlsbad, New Mexico, NCKRI Symposium 7, p. 221-226.

Ponta GML. 2019. Karst Hydrogeology: In Ponta GML, Onac BP (eds.) Cave and Karst Systems of Romania. Springer International Publishing, Cham, pp 41-47.

Ponta GML, McGregor SW, Jones SW. 2018. Hydrogeological assessment for Key Cave, Lauderdale County, Alabama: Alabama Geological Survey Open-File Report 1811, 57 p., 3 plates.

Povară I, Goran C, Gutt FW. 1990 Speologie; Ed Sport Turism, București, p 237. 
Shelton-Nix, Ericha, ed., 2017, Alabama Wildlife (v.

5): Tuscaloosa, The University of Alabama Press, $355 \mathrm{p}$.

U.S. Environmental Protection Agency. 1983. Methods for chemical analysis of water and wastes (revised edition): Cincinnati, Ohio, U.S. Environmental

Protection Agency, Environmental Monitoring and Support Laboratory, EPA/600/4-79-020.

U.S. Environmental Protection Agency. 1991. Methods for the determination of metals in environmental samples: Washington, D.C., U.S. Environmental Protection Agency, Office of Research and Development, EPA/600/4-91/010, 293 p.

U.S. Environmental Protection Agency, 1996, Drinking water regulations and health advisories: Columbus, Ohio, Environmental Resource Information Center. 